\title{
PRIVILEGED COMMUNICATIONS BEFORE FEDERAL ADMINISTRATIVE AGENGIES: THE LAW APPLIED IN THE DISTRICT COURTS
}

\begin{abstract}
Although testimonial privileges based upon attorney-client, husbandwife, physician-patient and other confidential relationships ${ }^{1}$ are generally recognized in the federal courts, ${ }^{2}$ their availability in federal adminis-
\end{abstract}

1 The privilege against compulsory disclosure accorded certain confidential communications is an exception to the general testimonial duty incumbent upon all persons. See 8 Wigmore, EvideNce §§ 2192, 2197 (McNaughton rev. 1961). Although the attorney-client and husband-wife privileges were recognized at common law, id. at $\S \S 2290,2333$, state legislatures have generally preempted the field. The statutes are collected id. at $\S \S 2292 \mathrm{n} .2$ (attorney-client), $2380 \mathrm{n} .5$ (physician-patient), 2286 n.21 (journalist-informant), 2286 n.22 (accountant-client), 2286 n.23 (psychologistpatient), 2395 n.l (priest-penitent). The privilege for communications between husband and wife has often been confused with the privilege accorded testimony as to anti-marital facts and with the older testimonial disqualification of a spouse. A by-product of this confusion is that the statutes often comprehend the several distinct policies. See id. at $\$ \S 2227-45$ (anti-marital facts), 2332-41 (marital communications) and particularly $\$ 2234$ (policies distinguished). The statutes are collected in 2 WigMore, Evidence $\$ 488$ (3d ed. 1940).

2 No federal court has denied that the privileges based upon confidential communications are available, but controversy and confusion surrounds the question of what body of law controls the existence and scope of particular privileges. Professor Moore maintains that under rule 43(a) of the Federal Rules of Civil Procedure, state privilege law controls. 5 MOORE, Federal Practice f 43.07 (2d ed. 1951) [hereinafter cited as MOORE]. This view is tempered in his discussion of privilege as it applies to the discovery rules. "The federal court ... . while respecting state statutes on privilege, should be free to give their own interpretation to the concept of privilege." His position is based upon the freedom of a federal court to construe the word "privileged" as it appears in the rules. 4 Moore I 26.23[9] (2d ed. 1962).

The suggestion that federal courts in both diversity and federal question cases are constitutionally bound to follow state privilege law under the rule in Erie R.R. v. Tompkins, 304 U.S. 64 (1938), in Louisell, Confidentiality, Conformity, and Confusion: Privileges in Federal Courts Today, 31 TuL. L. Rev. 101, 117-24 (1956), and the difficulty of applying a rule which provides only for the admissibility of evidence under state law, federal statute or prior federal equity rules, FED. R. CIv. P. 43(a), has provoked endless disagreement among the courts and commentators as to whether federal or state law must be applied. Cases can be found to support almost any view. See 2B Barron \& Holtzoff, Federal Practice and Procedure $\$ 967$ (1961) [hereinafter cited as Barron \& HoltzofF]. See also Pugh, Rule 43(a) and the Communication Privileged Under State Law: An Analysis of Confusion, 7 VaNd. L. Rev. 556, 570 (1954). A recent view is that at least in diversity cases, privilege is not a matter of procedure governed by the federal rules "since it goes to relationships established and maintained outside the area of litigation, and 'affect[s] people's conduct at the stage of primary private activity and should therefore be classified as substantive or quasi-substantive . . ." and thus controlled by state law under Erie. Massachusetts Mut. Life Ins. Co. v. Brei, 311 F.2d 463, 466 (2d Cir. 1962) (Waterman, J.) (quoting from Hart \& Wechsler, The Feneral Courts aNd the Federal System 678 (1953)). See the excellent discussion of the problem in Monarch Ins. Co. v. Spach, 281 F.2d 401, 407-09 (5th Cir. 1960).

The problem of evidentiary privileges as matters of "substance" has achieved such 
trative proceedings is presently the subject of controversy. ${ }^{3}$ Unfortunately, those courts faced with the problem have provided little enlightenment as to the doctrinal basis upon which such claims are to be honored or rejected.

proportions that the recent Judicial Conference report on federal evidence rules appears to have studiously avoided the cases and literature. CommirreE on RuLEs of Practice and Procedure, Judicial Conference of the United States, Preliminary Report ON THE Advisability and Feasibility of Developing UNIForm Rules of EviDENCE FOR THE United States District CourTs 29-40 (1962) (study prepared by the Reporter for the Special Committee on Evidence). The Special Committee on Evidence which prepared the report tentatively concluded that "rules of evidence, which would be uniform throughout the Federal court system, are both advisable and feasible." Id. at ix. One commentator has concluded, however, that: "A prudent committee would avoid privilege in state law cases. Advice which conflicts with the Erie doctrine as presently understood is more easily ignored by the Court than corrected by it." Degnan, The Law of Federal Evidence Reform, 76 HARv. L. REv. 275, 302 (1962).

For a view of Erie and its progeny which would leave questions of privilege to federal law and federal courts see Kurland, Book Review, 67 HARv. L. REv. 906 (1954) (answering some provocative questions posed in HART \& WECHSLER, op. cit. supra at 659-60). Professor Kurland maintains that only those rules which in advance of trial, taken in the abstract, are such as to substantially favor one side or the other in litigation should be controlled by state law. Kurland, supra at 915-16. See also Pretinminary REPORT op. cit. supra at 38.

Claims to privilege based upon confidential communications are uniformly recognized in both state administrative and judicial proceedings. Most state statutes are phrased in terms which generally prohibit the compulsion of testimony or place a duty of silence upon a confidant who comes within the terms of the act. See statutes referred to in note 1 supra. In the absence of a grant of administrative subpoena power exceeding that of the state courts, it is clear that the privilege would be available. See Note, Rights of Witnesses in Administrative Investigations, 54 HARv. L. REv. 1214, 1218-19 (1941). Section 10 of the Revised Model State Administrative Procedure Act provides that "agencies shall give effect to the rules of privilege recognized by law." National Conference of Commissioners on Uniform State Laws, Handbook and Procendings 215 (1961). The earlier Model Act and many state statutes contain similar provisions. See, e.g., MAss. ANN. LAws. ch. 30A, § II(2) (1962); CODE of VA. § 9-6.11(a) (1956); Mich. Stat. ANN. \& 3.560(21.5) (1961).

3 Although there is adequate authority recognizing the attorney-client privilege in IRS proceedings, see cases cited at note 7 infra, the Government unsuccessfully asserted in a recent case that the privilege was not available. United States v. Summe, 208 F. Supp. 925 (E.D. Ky. 1962). 'This claim as well as the uncertainty as to whether state or "federal" law governs difficult questions as to the scope of privilege prompted a recent note of concern from the Committee on Bulletin and Tax Notes, Section of Taxation, American Bar Association. Orkin, Attorney-Glient Privilege in Tax Matters, 49 A.B.A.J. 794 (1963). The CAB has posed a similar threat to the attorney-client privilege by maintaining that it is not available in Board investigations of air carrier associations and pressing the claim in the face of a district court decision to the contrary. Compare GAB v. Air Transp. Ass'n of America, 201 F. Supp. 318 (D.D.G. 1961), with Air Transp. Ass'n, 1A Av. L. Rep. I 21,355 (CAB Jan. 31, 1963). This latter controversy and the specter of Radiant Burners, Inc. v. American Gas Ass'n, 207 F. Supp. 771 (N.D. Ill. 1962), rev'd, 320 F.2d 314 (7th Cir. 1963) (the lower court had held the attorney-client privilege not available to corporations), petition for cert. filed, 32 U.S.L. WEEK 3104 (U.S. Sept. 5, 1963) (No. 439), prompted a quick reaction in print from the counsel of record for an intervening airline in Air Transport Association. See Miller, The Challenges to the Attorney-Client Privilege, 49 VA. L. REv. 262 (1963). 
A wide variety of federal agencies are empowered by congressional enactment to subpoena individuals and documents for the purpose of effecting their statutory responsibilities. 4 Nowhere in these statutes is mention made of privileged testimony or documents which would be immune to compulsory process. Instead, the legislation uniformly makes use of broad phraseology to the effect that all relevant documents or testimony shall be subject to subpoena.5 When called upon to enforce

4 E.g., Federal Trade Commission, 38 Stat. 722 (1914), 15 U.S.C. $\$ 49$ (1958); Securities and Exchange Commission, 48 Stat. 86 (1933), 15 U.S.C. $\S 77 \mathrm{~s}(\mathrm{~b})$ (1958) (Securities Act of 1933); 48 Stat. 900 (1934), 15 U.S.C. $\$ 78 u(b)$ (1958) (Securities Exchange Act of 1934); 49 Stat. 831 (1935), 15 U.S.C. \& 79r(c) (1958) (Public Utility Holding Company Act of 1935); 54 Stat. 842 (1940), 15 U.S.C. $\$ 80 \mathrm{a}-41$ (b) (1958) (Investment Company Act of 1940); 54 Stat. 85 (1940), 15 U.S.C. $\$ 80 \mathrm{~b}-9$-(b) (Investment Advisors Act of 1940); National Labor Relations Board, 61 Stat. 150 (1947), as amended, 29 U.S.C. \& 161(1) (1958); Federal Communications Commission, 48 Stat. 1096 (1934), as amended, 47 U.S.C. $\$ 409$ (e) (1958); Interstate Commerce Commission, 26 Stat. 743 (1891), as amended, 49 U.S.C. \$ 12(1) (1958); Administrator of the Federal Aviation Agency, 72 Stat. 753 (1958), 49 U.S.C. § 1354(c) (1958); Civil Aeronautics Board, 72 Stat. 792 (1958), 49 U.S.C. \& 1484(b) (1958); Commissioner of Internal Revenue, INr. REv. CoDE OF $1954, \S 7602$.

For the statutes of other agencies empowered to compel testimony and the production of documents see 1 Davis, Administrative LAw $\$ 3.03$ (1958) [hereinafter cited as DAvis]; I Barron \&: Holtzoff $\$ 30$ (1960). See also the list of agencies possessing subpoena power as of 1941 in Untred States Attornex General's Commirtee on administrative Procedure, Administrative Procedure in Government Agencies 41435 (1941).

5 See, e.g., INT. REv. CODE of 1954, § 7602: "For the purpose of ascertaining the correctness of any return, making a return where none has been made, determining the liability of any person for any internal revenue tax ... or collecting any such liability, the Secretary or his delegate is authorized-

(1) To examine any books, paper, records, or other data which may be relevant or material to such inquiry;

(2) To summon the person liable for tax or required to perform the act ... or any person having possession, custody, or care of books of account containing entries relating to the business of the person liable for tax or required to perform the act, or any other person the Secretary or his delegate may deem proper, to appear . . . and to produce such books, papers, records, or other data, and to give such testimony, under oath, as may be relevant or material to such inquiry ...." (Emphasis added.) Federal Trade Commission Act, 38 Stat. 722 (1914), 15 U.S.C. \& 49 (1958): "For the purposes of [the statutes entrusted to the Commission for enforcement] ... the Commission shall have the power to require by subpoena the attendance and testimony of witnesses and the production of all such documentary evidence relating to any matter under investigation." (Emphasis added.)

The language of the various acts seems wrought in a pattern that may be traced to the first Interstate Commerce Act: "[F]or the purposes of this act the [Interstate Commerce] Commission shall have power to require the attendance and testimony of witnesses and the production of all books, papers, tariffs, contracts, agreements, and documents relating to any matter under investigation ...." 24 Stat. 383 (1887) (as amended, 49 U.S.C. § 12(1) (1958)).

It should be noted that the federal Administrative Procedure Act makes no reference to privileged communications. Section $6(c)$ provides for the issuance of subpoenas authorized by law and directs that "upon contest the court shall sustain any such subpoena or similar process or demand to the extent that it is found to be in accord- 
agency subpoenas, ${ }^{6}$ however, the courts have refused to acknowledge such sweeping powers and have been disposed to maintain at least the common-law privileges ${ }^{7}$ even in the face of agency claims denying their availability. ${ }^{8}$

With the exception of controversies arising out of the administration of the Internal Revenue Code, the case law is scanty and rarely provides firm holdings. The Seventh Circuit has held that the FTC need not

ance with law . . ." 60 Stat. 240 (1946), 5 U.S.C. $\S 1005$ (c) (1958). If this provision were seen as defining the scope of available review it might obviate any claim of privilege not clearly provided for by statute since the legislative history indicates that it was intended to afford inquiry only into the jurisdictional power of the agency to issue the subpoena. Senate Comm. on the Judiciary, 79tr Cong. 2d Sess., Administrative Procedure Act-Legrslative History 27-28, 206, 227, 265, 363, 415 (Comm. Print 1946). No court has made reference to this section in deciding a privilege case, but it is likely that "in accordance with law" would be construed as permitting a broad inquiry into the question of privilege. See 1 Davis $\S 312$, at 216.

Although the first Model State Administrative Procedure Act was not approved until after the passage of the federal statute, drafts presented to the Conference of Commissioners on Uniform State Laws as early as 1942 contained the section directing compliance with the law of privilege. ProceEdings, op. cit. supra note 2, at 273 (1942). The legislative history of the federal act does not reveal advertence to this provision.

6 No federal agency has the power to directly enforce its own subpoenas. See ICC v. Brimson, 154 U.S. 447 (1894); 1 DAvIS \& 3.11. Statutes granting subpoena power to the agencies are uniformly accompanied by grants of jurisdiction to the federal district courts to entertain enforcement proceedings either on the motion of the agency itself or by virtue of an appearance by a United States Attorney. See statutes cited in I BARRON \& Holtzoff $\$ 30$ (1960). Although some acts provide criminal penalties for failure to comply with a subpoena, they have seldom been used and there is some indication that a subpoenaee can challenge the legality of a subpoena without subjecting himself to the threat of criminal conviction if he is wrong. See Comment, Procedures to Challenge the Process of Administrative Agencies, 30 U. CHI. L. Rev. 508 (1963).

The usual procedure is for the Government to file an action which requests that the district court order compliance with the subpoena. The defendant may answer setting up a defense but if he is unsuccessful an order will issue, the violation of which is punishable as contempt. Most circuits have held that such orders are appealable, e.g., O'Conner v. O'Connell, 253 F.2d 365 (1st Cir. 1958); Falsone v. United States, 205 F.2d 734 (5th Cir.), cert. denied, 346 U.S. 864 (1953). But see Application of Davis, 303 F.2d 601 (7th Cir. 1962), vacated as moot mem., 374 U.S. 495 (1963).

7 Colton v. United States, 306 F.2d 633 (2d Cir. 1962), cert. denied, 371 U.S. 951 (1963) (attorney-client) (IRS); Baird v. Koerner, 279 F.2d 623 (9th Cir. 1960) (attorneyclient) (IRS); United States v. Summe, 208 F. Supp. 925 (E.D. Ky. 1962) (attorney-client) (IRS); CAB v. Air Transp. Ass'n of America, 201 F. Supp. 318 (D.D.C. 1961) (attorneyclient); Gilles v. Del Guercio, 150 F. Supp. 864 (S.D. Cal. 1957) (marital) (review of deportation proceeding); SEC v. Harrison, 80 F. Supp. 226 (D.D.C. 1948) (attorneyclient). See also United States v. McDonald, 313 F.2d 832 (2d Cir. 1963) (attorney-client) (IRS); Sale v. United States, 228 F.2d 682 (8th Cir.), cert. denied, 350 U.S. 1006 (1956) (attorney-client) (IRS); Chapman v. Goodman, 219 F.2d 802 (9th Cir. 1955) (attorneyclient) (IRS); In re Wasserman, 198 F. Supp. 564 (D.D.C. 1961) (attorney-client) (IRS); Application of House, 144 F. Supp. 95 (N.D. Cal. 1956) (attorney-client) (IRS); United States v. Willis, 145 F. Supp. 365 (M.D. Ga. 1955) (attorney-client) (IRS).

8 United States v. Summe, supra note 7, at 926 (attorney-client) (IRS); CAB v. Air Transp. Ass'n of America, supra note 7 (attorney-client). 
honor a claim of accountant-client privilege. ${ }^{9}$ A district court has held that the $\mathrm{CAB}$ must honor the attorney-client privilege, ${ }^{10}$ and another district court has held that the SEC is similarly constrained. ${ }^{11}$ This small group of cases stands in contrast to the more developed body of doctrine fashioned in the enforcement of Internal Revenue subpoenas, where there is clear authority for the recognition of the attorney-client privilege $^{12}$ and indications that the physician-patient privilege will prevail when the issue is squarely presented. ${ }^{13}$ Claims to an accountantclient privilege before the IRS have been emphatically rejected.14

The major problem presented by the cases is the lack of self-conscious judicial attention to the question of what law should be applied when an administrative agency calls upon the courts to enforce a subpoena against a claim of privilege. The purpose of this comment is to determine whether or not there is a consistent doctrine that may be used in granting or rejecting such claims.

McMann v. SEC ${ }^{15}$ is an appropriate beginning. McMann sued his stockbrokers and during the course of litigation the SEC instituted an investigation into transactions in the shares of certain companies which had been traded by McMann through the brokers. It was suspected that he had paid supposedly disinterested parties to recommend the shares to the public, and the Commission subpoenaed the records of the brokerage account in the hope that they would disclose the illicit transactions. Although the brokers were prepared to comply, McMann asked the court hearing his original suit for an injunction pendente lite to restrain production of the documents. The injunction was denied and

9 FTC v. St. Regis Paper Co., 304 F.2d 731 (7th Cir. 1962). The claim was based upon an Illinois statute and was aimed at preventing the disclosure of material in the hands of an accountant who received it from a trade association to which St. Regis had reported. See text accompanying notes 60-62 infra.

$10 \mathrm{CAB}$ v. Air Transp. Ass'n of America, 201 F. Supp. 318 (D.D.C. 1961) (Holtzoff, J.). See also text accompanying notes 31-33 infra.

11 SEC v. Harrison, 80 F. Supp. 226 (D.D.C. 1948).

12 Cases cited at note 7 supra.

13 Sce In re Albert Lindley Lee Memorial Hospital, 209 F.2d 122, 124 (2d Cir. 1953), cert. denied, 347 U.S. 960 (1954); Gretsky v. Basso, 136 F. Supp. 640 (D. Mass. 1955). Both courts indicated that the privilege might be available if warranted by the circumstances, but found that the disclosures demanded did not constitute a breach of privilege. See text accompanying notes $57-59$ infra. The court in Gretsky suggested that the statutory protection from "unnecessary examination," INT. REV. CODE OF 1954, § 7605(b), might extend "to the taxpayer's interest in protecting its relationships with third parties." $136 \mathrm{~F}$. Supp. at 641.

14 Falsone v. United States, 205 F.2d 734 (5th Cir. 1953); Dorfman v. Rombs, 218 F. Supp. 905 (N.D. Ill. 1963). See also, e.g., Sale v. United States, 228 F.2d 682, 686 (8th Cir. 1956); Application of House, 144 F. Supp. 95 (N.D. Cal. 1956).

1587 F.2d 377 (2d Cir.) (L. Hand, J.), cert. denied, 301 U.S. 684 (1937). 
on appeal it was argued that the transactions were "confidential" and "privileged."16

No privilege for broker-client communications was known at common law and no state had created one by statute. Judge Learned Hand, writing for the court, adverted to the general duty of all persons to testify and the specific interests served by granting exceptions to that duty in the form of privilege. He rejected the broker-client relationship as a justifiable exception since "very near the end of the hierarchy of values which might dictate . . a privilege would be the secrecy of a man's speculations upon a stock market in an inquiry into the existence of trade practices which a statute has condemned."17

No quarrel may be had with this conclusion. The analysis, however, neglects a most important factor-the statute creating the agencies' subpoena power. Since the power to compel testimony is granted by congressional enactment it would seem that the enabling statute would have produced at least a starting point in the search for a rule of decision. ${ }^{18}$ The opinion, however, does not ask if the statute authorizing the SEC to issue such subpoenas either precludes, demands or allows the recognition of the privilege. Instead it rejects the claim and in so doing assumes "that the conduct of investigation under these statutes is subject to the same testimonial privileges as judicial proceedings . . . ."19

The bare holding in McMann is that there is no broker-client privilege before the SEC. It is based in part, however, on the assumption that SEC proceedings may be subject to the same testimonial privileges as would obtain before a court. We are not informed as to why this might be the case or what class of judicial proceedings might serve as a yardstick. Judge Hand's assumption has influenced subsequent courts and is partly responsible for the current confusion.

The assumption that investigations conducted by an administrative agency are subject to the same testimonial privileges as judicial proceedings served as a linchpin for the decision in Falsone $v$. United States. ${ }^{20}$ Falsone, an accountant, had been summoned by an IRS agent to appear and testify on matters pertaining to the tax liability of two of his clients who were then under investigation. He appeared but refused to testify and the Government obtained a district court order

$16 I d$. at 378.

17 Ibid.

18 Although the Supreme Court once indicated that this approach was appropriate, United States v. Louisville \&. N. R.R., 236 U.S. 318, 335-36 (1915), only one reported case rests on an interpretation of the relevant statute. CAB v. Air Transp. Ass'n of America, 201 F. Supp. 318 (D.D.C. 1961) (attorney-client). But cf. Falsone v. United States, 205 F.2d 734, 741 (5th Cir. 1953) (accountant-client) (IRS).

1987 F.2d at 378.

20205 F.2d 734 (5th Cir. 1953). 
directing compliance with the summons. On appeal it was argued that the matters under inquiry were cloaked by a testimonial privilege for communications between accountant and client.

The court opened its discussion of the privilege question by explicitly indulging in Judge Hand's assumption. ${ }^{21}$ It then reasoned that since the purported privilege was unknown at common law it could rest only upon a state or federal statute. ${ }^{22}$ The claim under a "federal statute" was based upon the statutory power of the Secretary of the Treasury to prescribe rules and regulations governing the recognition of agents or attorneys representing claimants before his department. The regulations provided for the qualification of certified public accountants as agents and Falsone was enrolled as such. He argued that since the regulations granted an agent the same rights, powers and privileges as an enrolled attorney, the testimonial privilege extended to communications with an attorney should accrue to an accountant as well. The court refused to accept this reasoning, holding that even if the regulations could be so interpreted they would conflict with the statute authorizing IRS investigations and the statute would prevail. ${ }^{23}$

The claim under state law was based upon a Florida statute creating an accountant-client privilege. Falsone argued that since the proceeding to enforce the subpoena was subject to the Federal Rules of Civil Procedure, state privilege law was applicable under rule 43(a).24 Granting that the rule might govern questions of privilege and refer to state law, the court nevertheless distinguished between the judicial proceeding to enforce an administrative subpoena, to which the federal rules applied, and the administrative proceeding itself, to which the rules were clearly inapplicable. ${ }^{25}$

21 The preliminary assumption was "that the conduct of investigations under this statute is subject to the same testimonial privileges as judicial proceedings . . . " 205 F.2d at 738 (citing McMann). The court took no notice of the fact that the statutory scheme for the regulation of the securities industry considered in McMann differed in both purpose and execution from that reflected in the Internal Revenue Code.

22 "Appellant concedes, as he must, that at common law no privilege was attached to communications from 'client' to accountant. If such a privilege exists, it can only arise from some federal or state statute." 205 F.2d at 739 .

23205 F.2d at 741 .

24 "All evidence shall be admitted which is admissible under the statutes of the United States, or under the rules of evidence heretofore applied in the courts of the United States on the hearing of suits in equity, or under the rules of evidence applied in the courts of general jurisdiction of the state in which the United States court is held. In any case, the statute or rule which favors the reception of the evidence governs ... . The competency of a witness to testify shall be determined in like manner." FED. R. Crv, P. 43(a). It is not at all clear that even under rule 43(a) a state privilege rule would be applicable. See note 2 supra.

$25205 \mathrm{~F} .2 \mathrm{~d}$ at 742 . The federal rules apply "to proceedings to compel the giving of 
The logic of the opinion is difficult to accept. If, as the court assumed by adopting Judge Hand's reasoning, the content of privilege law for an administrative proceeding is to be found in the practice of judicial tribunals, the court's subsequent analysis seems irrelevant. The treasury department regulations can hardly be seen to confer rights in judicial proceedings. The court, however, evaluated the treasury regulations as a source of law defining the powers of the IRS without reference to the practice of any court. Judge Hand's assumption seems abandoned sub silentio. Further, if judicial practice is to be adopted, the dictates of rule 43(a) might well be controlling, not of their own force, but by virtue of the original assumption. The court, however, clearly pointed out that administrative proceedings were not to be subject to the same rules as obtained before a court. ${ }^{26}$

The adoption of Judge Hand's assumption, rather than controlling the reasoning in Falsone, diverted attention from a thorough analysis of the problem. Without the assumption attention would first have been focused upon the statute. The court apparently held that the federal statute precluded the recognition of an accountant-client privilege. If this is true then no claim under state law could even have been entertained. Under such a view, however, it would be difficult if not impossible to distinguish the case where a claim of lawyer-client privilege was raised. The court avoided the potential dilemma by adopting Judge Hand's assumption and then impliedly placing common-law privilege in a favored position. ${ }^{27}$

The utility of basing an opinion in this field upon the assumption that judicial practice is applicable becomes clear when one observes a court that desires to uphold a claim of privilege against a Government contention that a statute authorizes the compulsion of any relevant testimony. In United States $v$. Summe $e^{28}$ the Government sought a court order to compel full compliance with an IRS summons issued to an attorney in connection with an investigation of the tax liability of two

testimony or production of documents in accordance with a subpoena issued by an officer or agency of the United States under any statute of the United States except as otherwise provided by statute or by rules of the district court or by order of the court in the proceedings ...." FED. R. Crv. P. 81(a)(3). (Emphasis added.) The Falsone court's distinction becomes clear when it is observed that the district court may modify the procedural rules at will. It certainly lacks the power to do the same to rules establishing the rights of the parties before the court.

26 "[S]peaking generally, the system of rules of evidence in force for trials by jury or even in courts of equity is not applicable, either by historical precedent, or by sound practical policy, to inquiries of fact determinable by administrative tribunals or officers." 205 F.2d at 742.

27 See note 22 supra.

28208 F. Supp. 925 (E.D. Ky. 1962). 
of his clients. The attorney refused to divulge information as to matters which he claimed were cloaked by an attorney-client privilege and the Government responded by arguing that the privilege was not applicable to proceedings under the Internal Revenue Code. ${ }^{29}$ While the opinion is confusing it appears to reason as follows: The "character" of the proceedings in question supports to "some extent" the Government's position that the attorney-client privilege is not applicable; but there "is doubt" as to the power to compel a lawyer's testimony about his client because the privilege derives from the common law and would be recognized if testimony were sought in a federal court; thus, since there is some authority to the effect that the privilege should be honored by the IRS and the "most forcible precedent" acknowledges the privilege in SEC proceedings; there being no case "squarely holding" that there is no privilege in investigative proceedings; "it is therefore necessary that the court proceed on the premise that the attorney-client privilege must be recognized at this investigation." 30

The problem in reading Summe is to discover the end to which the court marshals its logic. It is certainly not to construe the language of the statute. The provocative suggestion of the Government that the statute precludes the privilege is left unexplored. Even where an analogous precedent is relied upon, no consideration is given to the question of whether the inquisitorial powers of the IRS and the SEC display similarity of purpose and technique; or whether Congress may not have intended to shape entirely different institutions whose need to pierce the veil of privilege in order to carry out their mandates is not equally compelling.

Even where a court has felt constrained to consider the statute, the easy answer provided by a conclusory presumption has proved irresistible. In $C A B$ v. Air Transp. Ass'n of America ${ }^{31}$ the agency sought to compel the production of documents by means of an administrative subpoena duces tecum. The defendant, a trade association of air carriers, refused to comply, claiming that the material was protected by an attorney-client privilege. In the district court the agency argued that the attorney-client privilege could not be invoked before the $C A B$ by the trade association or its members in an investigation authorized under the appropriate provisions of the Federal Aviation Act. ${ }^{32}$ Without any consideration of the detailed and comprehensive investigative powers

29 Id. at 925-26.

30 Id. at 926-27. The court went on to define the scope of the privilege in the circumstances of the particular case, holding only one of six disputed questions to be improper.

31201 F. Supp. 318 (D.D.C. 1961) (Holtzoff, J.).

3272 Stat. $743,766,770$ (1958), 49 U.S.C. $\$ \$ 1324,1377,1385$ (1958). 
granted the Board by the statute, the court held the contrary. The opinion speaks for itself: "The attorney-client privilege is deeply embedded and is part of the warp and woof of the common law. In order to abrogate it in whole or in part as to any proceeding whatsoever, affirmative legislative action would be required that is free from ambiguity."33

It is not claimed that the courts have ignored a simple or obvious solution. The statutes give no indication that they are amenable to any particular interpretation as to privileged communications and Congress does not appear to have adverted to the problem when considering administrative procedure. ${ }^{34}$ On the other hand, assumptions and presumptions should be a last resort and not a favored device. The courts are at least obliged to exhaust legitimate doctrinal possibilities before deserting an agency's statutory framework in favor of ad hoc decisions which largely fail to provide guidance for future counseling or litigation.

There can be no doubt as to the power of Congress to establish or bar testimonial privileges in agency proceedings. This could be accomplished by a statute directed at the subpoena powers of a particular agency or in the form of general legislation on the order of the Administrative Procedure Act. ${ }^{35}$ Since Congress has not specifically dealt with the question, ${ }^{36}$ however, a claim of privilege before an agency can be viewed as presenting a problem of choice of law. If, for example, the statutes under which the agency demands enforcement fail to provide an explicit answer it may be argued that under the Rules of Decision Act, ${ }^{37}$ state law must govern. The act indicates an appropriate source of law for cases founded upon all jurisdictional grants. ${ }^{38}$ It expresses a general policy of conformity to local law and simultaneously

33201 F. Supp. at 318.

34 See note 5 supra. But cf. the solution of the problem under the Antitrust Givil Process Act, 76 Stat. 548 (1962), 15 U.S.C. 1312 (Supp. IV, 1963), discussed note 82 infra. 3560 Stat. 240 (1946), 5 U.S.C. 1005(c) (1958). But cf. Louisell, supra note 2, at 119-20.

36 The only federal statute governing privileged communications is section 21(a) of the Bankruptcy Act. It provides that a bankrupt or his spouse may be examined as to business transacted by the spouse or to which the spouse is a party "any law of the United States or of any State to the contrary notwithstanding." 32 Stat. 798 (1903), as amended, 52 Stat. 852 (1938), II U.S.C. \$ 44(a) (1958).

3728 U.S.C. $\S 1652$ (1958).

38 IA Moore |f 0.305[3] (1961); Hart \& Wechsler, The Federal Courts and the FeDERAL SYSTEM 697 (1963); Comment, Rules of Decision in Nondiversity Cases, 69 YALE L.J. 1428, 1431 (1960). See also, e.g., Sola Elec. Co. v. Jefferson Elec. Co. 317 U.S. 173 (1942) (federal law applied in a diversity case); Wichita Royalty Co. v. City Nat'l Bank, 306 U.S. 103 (1939) (state law applied in a case removed to federal court as one arising under the laws of the United States). For discussion of the resolution of the conflict between state and federal law in cases founded upon two important jurisdictional grants see GILMORE \& BLACK, AdMrralty 374-86 (1957); Hill, The Erie Doctrine in Bankruptcy, 66 HARv. L. REv. 1013 (1953). 
affirms the principle of the supremacy clause ${ }^{39}$ by asserting the superior authority of federal law: "The laws of the several states, except where the Constitution or treaties of the United States or Acts of Congress otherwise require or provide, shall be regarded as rules of decision in civil actions in the courts of the United States, in cases where they apply."40

A court is thus obliged to examine a federal statute when it arguably controls a contested issue. ${ }^{41}$ If the statute is silent there is at least a prima facie case for the application of state law.

Silence, however, is not always the final answer. The "recognized futility of attempting all-complete statutory codes" 42 inevitably presents the federal courts with the problem of deciding issues, arising within the framework of federal legislation, which are not resolvable with even the most supple techniques of construction, but which nevertheless may commend themselves to the application of "federal" law. These "interstices" 43 have often been filled with case-made federal law rather than with the law of some state.44 The line of demarcation between issues

39 U.S. CoNsT. art. VI.

4028 U.S.C. $\$ 1652$ (1958). The statute has been on the books in substantially the same form since its first enactment in 1789. For the historical background see Warren, New Light on the History of the Federal Judiciary Act of 1789, 37 HARv. L. REv. 49 (1923); I Crosskey, Politics and the Constirution 627 (1953); 2 id. at 865-66, 912-37.

41 When, as in the case of the enforcement of administrative subpoenas, jurisdiction is conferred by the same statutes which create the agency's subpoena power, the duty to examine the relevant legislation becomes self-evident. See statutes cited I BarRoN \& HoltzofF \$ 30 (1960).

42 Mr. Justice Jackson concurring in D'Oench, Duhme \& Co. v. FDIC, 315 U.S. 447,470 (1942).

43 "I recognize without hesitation that judges do and must legislate, but they can do so only interstitially; they are confined from molar to molecular motion." Mr. Justice Holmes dissenting in Southern Pac. R.R. v. Jensen, 244 U.S. 205, 221 (1917).

44 See generally IA MOORE I $0.319-0.324$. Authoritative justification for invoking the powers of "interstitial" legislation to supply a federal rule where the statute cannot be construed to provide an answer is rarely forthcoming. Professor Mishkin puts it that there "must" be competence in the federal courts to declare a "federal" rule when a problem "bear[s] substantial relation to an established federal operation." Mishkin, The Variousness of "Federal Law": Competence and Discretion in the Choice of National and State Rules for Decision, 105 U. PA. L. REv. 797, 799 (1957). As to the Rules of Decision Act he concedes that the general problem "could be viewed as a matter of the interpretation of that act" in that "it could be said that there is a substantial penumbra surrounding each program of congressional legislation where indeed 'the Constitution . . . or Act of Congress otherwise require' that state law be automatically applied." Id. at 800-01 n.16. But since the "terms of the act are "almost perversely uninformative," " and furthermore "judicial authority has often said that the act is merely declarative of the rule which would exist in the absence of the statute' ... [it] is significant principally as an expression of an underlying policy ...." Ibid. But cf. Comment, supra note 38, at 1432-34. While it may be true that the supremacy clause sketches the farthest reach of any statute asserting the authority of federal law, it is equally true that Congress could limit its effect by 
deserving of one alternative or the other is difficult to discern. "Federal" law has been invoked for a confusing array of reasons which may seem persuasive in individual cases but which ultimately fail to frame a coherent doctrine. ${ }^{45}$

It has been said that in an instance not particularly treated by a statute, congressional legislation may have established a particular policy which provides a federal rule sufficient to prevent the adoption of state law under the Rules of Decision Act. ${ }^{46}$ Some cases have gone beyond this to suggest that the policy of a legislative program may be such as to demand the wholesale, a priori, rejection of state law in favor of federal rules of decision in all those instances where the federal statute does not provide a specific answer. ${ }^{47}$ Although there has been cogent criticism of the lack of precision with which the courts have justified the development of "federal" rules in such instances, ${ }^{48}$ the cases can be understood as at least establishing that when a federal program may be hampered in its administration and effect, the courts feel justified in interpreting the Rules of Decision Act in a manner that avoids the application of state law. 49

setting a more stringent standard for the displacement of state law than that which the courts have adopted. It could demand that state law be followed except where "Acts of Congress specifically otherwise require or provide." Even if discretion "must" exist, Congress in its wisdom could deny it to the federal judiciary. Thus it would seem that focus upon even "perversely uninformative" language might serve as a useful reference point or even as a check upon the degree of discretion with which Congress has endowed the courts. Note, 53 Colum. L. REv. 991, 1002-08 (1953).

45 "The line between situations where reference must be made to state law and those where federal decisional law will control is not clear. Specific situations have been faced and decided; to categorize or generalize from specific rulings is not easy. The courts may talk in terms of the intent of Congress, the relationship with state agencies, whether the right is 'purely a creature of congressional enactment,' whether following state law would frustrate a federal policy, whether a right, duty or status is created by a state. Certain areas are so "dominated by the sweep of federal statutes that legal relations which they affect must be deemed governed by federal law ... ." IA MOORE If 0.323[22], at 3757-58. (Citations omitted.)

46 See, e.g., Sola Elec. Co. v. Jefferson Elec. Co., 317 U.S. 173, 176 (1942); Fahs v. Martin, 224 F.2d 387, 392 (5th Cir. 1955).

47 Textile Workers Union v. Lincoln Mills, 353 U.S. 448 (1957); cf. United States v. Standard Oil Co., 332 U.S. 301 (1947); Clearfield Trust Co. v. United States, 318 U.S. 363 (1943). Although the opinion in Lincoln Mills marshalled the "intent" of Congress to support the assertion of federal law, it failed to make a convincing argument in that regard. See Mr. Justice Frankfurter's dissent, 353 U.S. at 460.

48 Comment, supra note 38, at 1428-29, 1442, 1452.

49 It has been suggested that the Supreme Court indicated that the presence of the Government as a party to litigation is decisive in establishing a basis for the rejection of state law and the applicability of a "federal" rule. Id. at 1428, 1439, 1442. See also, e.g., United States v. Standard Oil Co., 332 U.S. 301 (1947); Clearfield Trust Co. v. United States, 318 U.S. 363 (1943); cf. Bank of America v. Parnell, 352 U.S. 29 (1956). It seems wholly arbitrary that the sole fact of Government participation in an 
Thus, if a federal court fails to find satisfactory answers to the problem of privilege in the enabling statutes of a particular agency, it should either apply state law or articulate some basis upon which it may be replaced by federal decisional law. The cases indicate that state law has not been considered competent authority. Only one circuit has explicitly applied state law to uphold a claim of common-law privilege $\mathrm{e}^{50}$ and

action should be viewed as either a sufficient or necessary condition for the displacement of state law. The cases can be read for the alternative proposition that the effect on the particular Government program at issue is a more reasonable guideline for determining whether federal or state law should be applied. "The application of state law ... [to Government issued commercial paper] would subject the rights and duties of the United States to exceptional uncertainty. It would lead to great diversity in results by making identical transactions subject to the vagaries of the laws of the several states." Clearfield Trust Co. v. United States, supra, at 367. See also Bank of America v. Parnell, supra, at 33-34; United States v. Standard Oil Co., supra, at 809-10; cf. International Ass'n of Machinists v. Central Airlines, Inc., 372 U.S. 682 (1963). "There is no reason to believe that ... Congress discarded for an entire industry an element essential to a reliable system of settling disputes under existing contracts or that it contemplated awards by adjustment boards the enforceability of which depended entirely on the desires of the parties or upon state statutes or court decisions." Id. at 695. (Emphasis added.) Professor Mishkin has suggested what might be read as a more open-ended test. He proposes that as to problems bearing substantial relation to an established federal operation "state law cannot govern of its own force; there must be competence in the federal judiciary to declare the governing law." Mishkin, supra note 44, at 799. An alternative formulation offered in a footnote seems to deprive the assertion of any value as test for the displacement of state law. The power to declare the governing law "must extend to any issue as to which a tenable (i.e., non-frivolous) claim can be made that the decision could have impact on the operation of congressional legislation." Id. at 800 n.15. This does not even seem to go so far as to delimit a prima facie case for the invocation of "federal" law under the "otherwise require or provide" clause of the Rules of Decision Act. It says only that the federal court has the power to decide between state and federal law -that is, the power to construe the "otherwise require or provide" clause as meaning more than "specifically otherwise require or provide." As to whether state or federal decisional law should govern in any particular instance, Professor Mishkin indicates that he would not only consider the value to be obtained from asserting federal law to protect the effectiveness of a federal program, but that such gain must be balanced against "the potential losses from non-integration of the national program with normal state activities." Id. at 312; cf. De Sylva v. Ballentine, 351 U.S. $570,580-82$ (1956).

50 Baird v. Koerner, 279 F.2d 623 (9th Cir. 1960). "While the authority under which the proceedings below were instituted stems from congressional enactment, that does not mean that there exists a federal common law defining the nature and extent of the privilege between attorney and client." Id. at 627 . The court relied in part on its view that the enforcement proceeding was a "civil case" governed by the Federal Rules of Civil Procedure and that rule 43 (a) indicated a reference to state law to determine questions of privilege. Id. at 628. The court in Falsone properly rejected a similar proposition on the grounds that the federal rules were inapposite to the determination of the substantive issues raised by the enforcement proceeding. See text accompanying notes 24-25 supra. Accord, Colton v. United States, 306 F.2d 633, 636 (2d Cir. 1962); FTC v. St. Regis Paper Co., 304 F.2d 731, 734-35 (7th Cir. 1962); United States v. Summe, 208 F. Supp. 925, 926 (E.D. Ky. 1962). The difficulty presented by the opinion in Baird can be seen in the court's own summation of its 
novel ${ }^{51}$ state privileges have been uniformly denied recognition. ${ }^{52}$ Further, the cases are replete with statements to the effect that "federal law" governs the question ${ }^{53}$ and that federal investigations "may not be prevented by matters depending upon state law."54 Since the relevant legislation has only occasionally been adverted to, and nowhere analyzed, it is clear that the statutory language is not the source of the applicable "federal law." 55

A tentative conclusion is justified. The courts have not found statutory materials explicitly indicating rules of decision for privilege cases. They have, however, rejected the authority of state law assumedly because federal policies reflected in the statutory programs of the agencies outweigh those supporting the recognition of state privileges. ${ }^{56}$

grounds for decision: "[W]e find (I) that because the relationship of client and attorney is created and controlled by the law of the various states; and that such creation and control is recognized, followed, and approved by the federal courts, the nature and extent of the privilege created between a lawyer and his client by the attorney-client relationship requires the federal courts to follow the state law; (2) that some considerable number of federal cases enunciate the rule that the state law governs the rule of privilege; (3) that some federal cases apply the law of the forum state, but do so without enunciating the principle under which they act; (4) that no federal statute forbids the use of the law of the forum state, and that if there is any definite rule set up by federal statute it requires us to follow the law of the forum state, and (5) any federal 'common law' which may exist does not require us to ignore the forum state law; (6) that general policy considerations applicable to the law of privilege between attorney and client support the rule of privilege in this case; (7) that each case must stand on its own facts, with the courts balancing the public policy considerations involved, and we hold the law of the forum state should and does control-here the State of California." Id. at 632. Although points 2, 3, 4, and 5 may be read as a use of rule 43 (a), the policy arguments and the discretion implicit in the remaining conclusions cannot take on importance unless the rule is not applicable and the court is free to declare the law of privilege for the purposes of an administrative investigation.

51 "Novel" is used to indicate a privilege unknown at common law rather than one rarely recognized or of recent date. See note 1 supra.

52 FTC v. St. Regis Paper Co., 304 F.2d 731 (7th Cir. 1962) (accountant-client) (IRS); Falsone v. United States, 205 F.2d 734 (5th Cir. 1953) (accountant-client) (IRS); cf. In re Albert Lindley Lee Memorial Hosp., 209 F.2d 122 (2d Gir. 1953) (physicianpatient) (IRS); Gretsky v. Basso, 136 F. Supp. 640 (D. Mass. 1955) (physician-patient) (IRS).

53 E.g., Colton v. United States, 306 F.2d 633 (2d Cir. 1962); In re Albert Lindley Lee Memorial Hosp., supra note 52, at 123; United States v. Summe, 208 F. Supp. 925, 927 (E.D. Ky. 1962); Gretsky v. Basso, supra note 52, at 641; cf. FTC v. St. Regis Paper Co., supra note 52, at 734; Falsone v. United States, supra note 52, at 741-42.

54 Falsone v. United States, 205 F.2d 734, 742 (5th Cir. 1953).

55 Examination of the statutes supports this conclusion in that the use of general language in conferring investigatory powers makes it impossible to glean any specific policy as to privileged communications. See statutes cited at notes 4-5 supra.

56 The point might be made with greater clarity if one asserted that the courts were avoiding the application of state law under the Rules of Decision Act by an expansive interpretation of the "otherwise require or provide" clause. See text accompanying notes $37-49$ supra. See also Comment, supra note 38 , at $1428,1433,1434$, 
This conclusion is buttressed by evidence in several cases that where novel privileges are rejected, their underlying policies are weighed against the competing claims of the agency. In In re Albert Lindley Lee Memorial Hosp. ${ }^{57}$ the IRS had subpoenaed the hospital's records during the course of an inquiry into the tax liability of an affiliated doctor. When the hospital refused to comply, the Government sought an enforcement order and the physician intervened. It was claimed that the records were protected by a state physician-patient privilege but the district court, applying state law, held that the records were not privileged. ${ }^{58}$ The Second Circuit affirmed but specifically rejected the applicability of state law. After asserting that "federal law" governed and indulging in Judge Hand's familiar assumption, the court proceeded to analyze the circumstances of the subpoena. It concluded that since only the fact of hospital treatment and not its nature was to be disclosed, "the public interest in the collection of taxes owing by a taxpayer outweighs the private interest of the patient to avoid embarrassment resulting from being required to give the revenue agent information as to fees paid the attending physician." 59

Again in FTC v. St. Regis Paper Co. ${ }^{60}$ the court denied the applicability of state law and went on to evaluate the claim of privilege as an original question. St. Regis attempted to protect information which had been turned over to a trade association of which it was a member. The association in turn gave the material to its Chicago accountants. Responding to the assertion of an Illinois statute ${ }^{61}$ the court observed that:

We are not persuaded that the relationships between several members of a trade association and the association accountant should be considered a relationship equally valued, for the same reason, as the personal relationship between husband and wife, priest and penitent, physician and patient, when to do so would result in a frustration of the Federal Government's performance of a necessary investigatory function. ${ }^{62}$

1437-42. Ironically, the only reference to the act or its policies is in an opinion which ultimately found state law to be applicable. Baird v. Koerner, 279 F.2d 623, 627 (9th Cir. 1960) (attorney-client) (IRS).

57209 F.2d 122 (2d Cir. 1953).

58 Id. at $122-23$.

59 Id. at 124.

60304 F.2d 731 (7th Cir. 1962).

61 "Accountant as witness. A public accountant shall not be required by any court to divulge information or evidence which has been obtained by him in his confidential capacity as a public accountant." ILL. REv. STAT. ch. 110 1/2, § 51 (1961).

02 304 F.2d at 734 . 
It is clear that at least where the courts have refused to recognize a novel privilege claimed under state law they do so as a matter of "federal" law and because of the importance placed upon the investigative function of the agency. ${ }^{63}$

These cases provide only preliminary evidence as to the possible nature of a coherent doctrine. Despite the rejection of state law and indications of an independent evaluation of privilege, they may indicate nothing more than discrete judgments refusing effect to state law where the effective prosecution of a federal policy may be hampered. ${ }^{64}$ While such decisions might be characterized as interstitial judicial legislation, they would be of limited significance. It is difficult to quarrel with an interpretation of the Rules of Decision Act that allows a federal court to extend the policy of a statute to the point where it is at least protected from frustration by local legislation. ${ }^{65}$

The cases involving the attorney-client privilege indicate, however, that the courts have gone beyond the mere protection of federal programs from frustration. All federal courts which have considered the matter have held that the privilege was available before administrative agencies, ${ }^{60}$ although some have found it inapplicable in the circumstances of the case.67 The opinions have been almost unanimously indifferent to state law. 68 Thus, if state law is not considered relevant, it must be assumed that the prosecution of a federal program demands a result that is contrary to the policy of local conformity explicit in the Rules of Decision Act. This much might be consistent with the rejection of a privilege claimed under state law. Where, however, the courts purport to recognize an attorney-client privilege-its substance to be

63 Cf. Falsone v. United States, 205 F.2d 734, 742 (5th Cir. 1953).

04 The independent policy analysis does, however, indicate that these courts might be willing to recognize certain privileges as a matter of federal law. It should be recognized that this involves an analysis which has not been made explicit by any court: That the "otherwise require or provide" clause of the Rules of Decision Act permits a rejection of state law because the policy of the federal program concerned indicates that the privilege should be recognized. The difficulties with this position are discussed in connection with the attorney-client cases. See text accompanying notes 65-71 infra.

65 Cf. Anderson v. Abbott, 321 U.S. 349 (1944) (shareholders of holding company liable for assessment on shares of national bank in company portfolio). "It is of course true that Delaware created this corporation. But the question of liability for these assessments is a federal question. The policy underlying a federal statute may not be defeated by such an assertion of state power." Id. at 365 .

66 See cases cited at note 7 supra.

67 E.g., Colton v. United States, 306 F.2d 633 (2d Gir. 1962); Sale v. United States, 228 F.2d 682 (8th Cir. 1956); In re Wasserman, 198 F. Supp. 564 (D.D.C. 1961); Gretsky v. Miller, 160 F. Supp. 914 (D. Mass. 1958).

68 The exception is Baird v. Koerner, 279 F.2d 623 (9th Cir. 1960). See note 50 supra. 
delineated by reference to some nonauthoritative body of law ${ }^{69}$-they have progressed beyond a simple recognition of the supremacy of federal interests.

While it is justifiable to invoke a doctrine of interstitial legislation to prevent frustration of agency investigations, the recognition of a "federal" privilege cannot be so justified. When federal case-made law is applied in preference to state law its legitimacy must rest upon a judgment that the federal program demands a rule tailored to its requirements. In the case of privileged communications before federal agencies it is difficult to see how the recognition or creation of a privilege can be characterized as a doctrine in aid of the agencies' program. The privilege can only prevent an agency from obtaining information to which it is arguably entitled under its enabling legislation. In an enforcement proceeding $\cdot \mathrm{a}$ court merely acts to vindicate the statutory power of the agency. To limit such power where the rule cannot be seen as within the scope of the statute is an unwarranted assertion of judicial power. ${ }^{70}$

69 The doctrine drawn upon to deal with claims of attorney-client privilege has been developed entirely from undifferentiated federal and state cases and the authoritative text of Dean Wigmore's treatise. See, e.g., Colton v. United States, 306 F.2d 633, 636-40 (2d Cir. 1962) (Wigmore and federal civil and criminal cases); United States v. Summe, 208 F. Supp. 925, 927-28 (E.D. Ky. 1962) (Wigmore and federal civil and criminal cases); In re Wasserman, 198 F. Supp. 564, 566-67 (D.D.C. 1961) (federal civil and criminal cases, a Missouri case, a Minnesota case and Wigmore); Gretsky v. Miller, 160 F. Supp. 914 (D. Mass. 1958) (federal civil and criminal cases, a Massachusetts case and Wigmore). The opinions fail to indicate how either the sources or substance of their doctrine provide rules inherently more protective of federal interests than those which would result from the application of state law.

70 The recognition of a "federal" privilege implies two assertions of policy: (1) That the relationship between lawyer and client is deserving of consideration and support to the extent of depriving an agency of information that may be of importance to the administration of a federal program; and (2) That the effective administration of a federal program demands that a uniform privilege doctrine obtain. The second assertion appears to be the only one worthy of analysis since if the attorneyclient relationship is valued it may be honored in the form of deference to state privilege.

While the need for uniformity in the administration of federal programs is often offered as a justification for the displacement of state law it is rarely subjected to careful analysis. "Thus, not infrequently the call for 'uniformity' seems basically to represent a desire for symmetry of abstract legal principles and a revolt against the complexities of a federated system of government." Mishkin, supra note 44, at 813 . One is hard put to find weighty reasons that demand "uniformity" in privilege doctrine as it applies to federal administrative agencies. The "vagaries of state law" may be guarded against by an outright rejection of any claim based upon state doctrine that is judged to be seriously disruptive of a federal legislative program. Indeed, the IRS and FTC have been amply protected from claims to accountant-client privilege based upon state law. FTC v. St. Regis Paper Co., 304 F.2d 731 (7th Cir. 1962); Falsone v. United States, 205 F.2d 734 (5th Cir. 1953). While it might be claimed that all individuals subject to federal power should have equal rights and duties vis-à-vis the Government, it is equally true that there may be reliance upon the existence of local 
While this analysis indicates that the cases recognizing the attorneyclient privilege as a matter of federal law are unwarranted, there is an alternative explanation that could support their results and perhaps provide a doctrinal framework for the resolution of claims of privilege before the agencies.

The cases recognizing the attorney-client privilege but refusing to uphold a particular claim could be viewed as defining the outer limits of state privilege doctrine as applied to the agencies. Privilege would reach only to the point where these cases have drawn the line. Beyond, to cloak information behind a privilege would frustrate a federal program to a degree which may not be tolerated. The original claim would, however, have to be based upon state law and in the absence of compelling federal considerations that law would be authoritative and controlling under the Rules of Decision Act. ${ }^{71}$

privileges, see Comment, 71 Yale L.J. 1226, 1269-70 (1962), and that the Rules of Decision Act appears to indicate that local law should be apposite in the absence of a compelling federal interest. Finally, the administrative burden upon the agencies of adopting investigative policies tailored to local rules is de minimis and could hardly be seen to justify discarding the judgment of Congress that local conformity should prevail where the Constitution or statutes "do not otherwise require or provide."

71 See notes 37-49 supra and accompanying text. The application of state law under the Rules of Decision Act would raise one problem that has not been referred to in the opinions: If state law is to be applied, which state's law is controlling and is that question to be decided by the conflicts-of-law rules of the forum state or is the federal court free to declare its own conflicts rule? The Supreme Court has held that in diversity cases the conflicts law of the forum must be applied to determine the law governing issues that rest upon out-of-state circumstances. Klaxon Co. v. Stentor Elec. Mfg. Co. 313 U.S. 487 (1941). On several occasions the Court has reserved the question of whether Klaxon applies when jurisdiction is not based upon diversity of citizenship. See McKenzie v. Irving Trust Co., 323 U.S. 365, 371 n.2 (1945); D'Oench, Duhme \& Co. v. FDIC, 315 U.S. 447, 455-56 (1942). Several commentators have made suggestions to the effect that whether Klaxon applies should depend upon the nature of the reference to state law. If it is such that the federal court is enforcing a state-created cause of action and there is no distinctive federal interest involved Klaxon would be appropriate. On the other hand, state elements in federal causes of action should leave the federal courts free to declare their own conflicts rules. Note, 68 Harv. L. Rev. 1212, 1228-29 (1955). Professor Moore would examine the federal policies in the matter before the court and determine if they "refer to or incorporate" state law and if so, state law, including conflicts rules, must be applied. IA MOORE I 0.325 , at 3769-70. This appears to mean that if state law applies, state conflicts law applies and provides an answer to the question if not a reasoned argument.

Either federal or state conflicts doctrine will present more than the usual difficulty in arriving at a rule for privileged communications. In particular, the issue of a conflicts rule to be applied in federal administrative agency cases will be troublesome. The general rule is that the law of the forum determines the admissibility of evidence, Restatement, Conflict of LAWs $\$ 597$ (1934), but privilege doctrine does not go to the management of the trial in the interests of accurate factual determinations. It is supposedly based upon an extrinsic policy of fostering and protecting the communicative value of particular relationships. 8 WIGMORE, EVIDENCE \& 2285 (McNaughton rev. 1961). "The public policy under this theory is effective at the point where the communication takes place and not during the litigation." Weinstein, Recognition in the 
The courts do not seem disposed to follow such an approach. Indeed their insistence upon "federal" law, the eclectic choice of materials used to fashion doctrine, ${ }^{72}$ and the widespread use of Judge Hand's "assumption" seems to indicate a resistance to discrete decisions affirming or rejecting state privileges. Perhaps the explanation lies in the unique nature of the attorney-client privilege. ${ }^{33}$ Despite current criticism of evidentiary privileges, ${ }^{74}$ the attorney-client protection is still highly val-

United States of the Pritileges of Another Jurisdiction, 56 Colum. L. REv. 535, 536 (1956).

Although the interstate nature of the businesses that are the peculiar subject of federal administrative regulation may create difficulties in establishing the "place of the communication" and may invite forum shopping, the federal courts would retain the ultimate power to reject any claim that clearly frustrated an investigative program. An alternate rule would very likely be without rational foundation since both the place of the administrative inquiry as well as the forum in which the enforcement proceeding takes place are subject to arbitrary location.

72 See note 69 supra.

73 Despite the brevity with which Judge Holtzoff disposed of the problem in $A$ ir Transp., see text accompanying note 33 supra, he offered a provocative idea which might account for the unique status of a "federal" lawyer-client privilege: "The very existence of the right of counsel necessitates the attorney-client privilege in order that a client and his attorney may communicate between themselves freely and confidentially." 201 F. Supp. at 318. Section 6(a) of the Administrative Procedure Act, establishes the right of any person compelled to appear before an agency to be represented by counsel. 60 Stat. 240 (1946), 5 U.S.C. $\$ 1005$ (a) (1958). It could be persuasively argued that this legislative command to the administrative agencies carries with it a parallel requirement that testimonial privilege be accorded communications between a subpoenaee and his present and former counsel. The statute could be interpreted as a federal adoption of the policy of the privilege. Further, since criminal prosecution may result from circumstances under investigation by an agency, the denial of privilege for communications with counsel who will represent one before the agency may be an effective denial of the protection of the privilege against self-incrimination. The agency could subpoena the attorney and elicit incriminating information which would then be spread upon the public record. But see Application of House, 144 F. Supp. 95, 99-102 (N.D. Cal. 1956); cf. People v. Minkowitz, 220 N.Y. 399, 115 N.E. 987 (1917).

74 See McCoRMICK, EvIDENCE $\S 81$ (1954). "The manifest destiny of evidence law is a progressive lowering of the barriers to truth. Seeing this tendency, the commentators who take a wide view, whether from the bench, the bar, or the schools, seem generally to advocate a narrowing of the field of privilege. ... One may hazard a guess ... that in a secular sense privileges are on the way out." Id. at 165-66. See also VANDERbilt, Minimum Standards of Judicial Administration 583-84 (1949) (Report of the Section of Judicial Administration of the American Bar Association); cf. Radiant Burners, Inc. v. American Gas Ass'n, 207 F. Supp. 771 (N.D. Ill. 1962) (attorney-client privilege denied to corporations), rev'd, 320 F.2d 314 (7th Cir. 1963), petition for cert. filed, 32 U.S.L. WEEK 3104 (U.S. Sept. 5, 1963) (No. 439). Professors Kurland and Morgan on the brief for appellees argued persuasively, albeit unsuccessfully, that "it has never been demonstrated, however often asserted, that the benefits to be derived from the hobbling of the judicial process by the doctrine of privileged attorney-client communications exist, no less that they are superior to the benefits of full disclosure that is the principle upon which the entire judicial process depends." Brief for Appellee, p. 18, Radiant Burners, Inc. v. American Gas Ass'n, 207 F.2d 314 (7th Cir. 1963). 
ued, particularly by the bar from whose ranks the bench is almost universally recruited. 75

To adopt a case by case approach evaluating state privileges in the light of a federal program would inevitably confront the courts with the problem of establishing a policy basis for distinguishing between the virtues of an attorney-client privilege and those, for example, of an accountant-client privilege. Given a claim under the latter, the scope of which was no greater, or perhaps less, than that usually afforded the former, one would be hard pressed to find a requirement of federal policy that would justify refusing to honor the novel privilege. The cases, however, have clearly rejected state accountant-client privileges ${ }^{76}$ and even the physician-patient privilege has been denied explicit recognition ${ }^{77}$ where that of the attorney-client has been recognized in obiter dicta. ${ }^{78}$

Little can be said for the existing state of the case law. The refusal to recognize a privilege as applicable to a federal agency may be justified as necessary to the effective prosecution of a federal program, but the assumption that judicial privileges obtain and the explicit recognition of a "federal" attorney-client privilege are not warranted by any doctrine explicitly or implicitly adopted by the courts. ${ }^{79}$

75 In response to a questionnaire circulated by the Yale Law Journal 107 of 132 attorneys replied that they did not believe that the attorney-client privilege "signifcantly disrupts the administration of justice" but 38 of 125 were of the opinion that the rule resulted in evidence being kept out that was not available through some other source. 101 of 125 felt that the privilege should not be further hemmed in by limitations. Comment, supra note 70 , at 1271. Of 47 judges surveyed 43 felt the privileged communications rule to be "an obstructive one," but 42 stated that it was not "significantly disruptive" of the administration of justice. All who expressed an opinion (40) did not think that the privilege should be subject to further limitations. Id. at 1272. The symbolic importance of the privilege for the legal profession is mirrored in Judge Holtzoff's inapposite invocation of the common law in Air Transport. See text accompanying note 33 supra. To see the ancient doctrine of strict construction for statutes in derogation of the common law invoked in a civil case before a federal court in $\mathbf{1 9 6 2}$ is to witness a spontaneous professional reaction. It seems almost unthinkable that the sovereign prerogative of privilege could be abrogated by a governmental parvenu-the administrative agency.

76 FTC v. St. Regis Paper Co., 304 F.2d 731 (7th Cir. 1962); Falsone v. United States, 205 F.2d 734 (5th Cir. 1953); Dorfman v. Rombs, 218 F. Supp. 905 (N.D. III. 1963).

77 In re Albert Lindley Lee Memorial Hosp., 209 F.2d 122 (2d Cir. 1953); Gretsky v. Basso, 136 F. Supp. 640 (D. Mass. 1955).

78 Cases cited note 67 supra.

79 Significantly, there has been no attempt to examine an agency program in order to determine the nature of its need for information and the implications of the particular proceeding for which a subpoena is authorized. While adjudicative hearings might, without detailed analysis, be analogized to judicial proceedings, a self-informing investigation or rule-making hearing may present different problems that deserve particular attention. Compare 1 Davis $\S 820$, with id. at $\S 314$, and id. at $\S 6.12$. 
While the efforts of the judiciary to deal with problems in this field may be subject to criticism there is little doubt that ultimate responsibility for the confusion and lack of clearly articulated standards must rest with the agencies themselves or with Congress. All of the agencies concerned have the statutory power to make rules that are not inconsistent with their enabling legislation. ${ }^{80}$ Rules declaring that certain privileges will or will not be available are probably within such powers. ${ }^{81}$ No agency, however, has exercised the rule-making power in this regard

While the statutes themselves do not offer clear guidelines one would expect that a court exercising the power of "interstitial legislation" would feel constrained to examine the interests at stake and provide a reasoned opinion reflective of its determination.

80 E.g., "The [SEC] ... shall have authority from time to time to make, issue, amend, and rescind such rules and regulations and such orders as it may deem necessary or appropriate in the public interest or for the protection of investors to carry out the provisions of this title . . ." 53 Stat. 1173 (1939), 15 U.S.C. § 77sss(a) (1958). See also 48 Stat. 901 (1934), as amended, 15 U.S.C. $\$ 78 w(a)$ (1958) (SEC); 72 Stat. 643 (1958), 49 U.S.C. § 1324(a) (1958) (CAB); 38 Stat. 721 (1914), 15 U.S.C. § 46(g) (1958) (FTC); INT. REv. CODE of 1954, \& 7805(a).

81 A rule declaring a privilege would be the voluntary act of the agency depriving itself of information in certain cases whether or not it possessed the power of compulsion. The only class of persons who might have standing to object to such a rule would be litigants before an agency who were deprived of the opportunity to identify and enter into the record information that could be cloaked behind the privilege. Section 6(c) of the Administrative Procedure Act requires that "agency subpoenas authorized by law shall be issued to any party upon request and, as may be required by rules of procedure, upon a statement or showing of general relevance and reasonable scope of the evidence sought." 60 Stat. 240 (1946), 5 U.S.C. \& 1005(c) (1958). It might be argued that this establishes the right of a party to an appropriate subpoena if it is within the statutory power of the agency. Thus the validity of a rule which arguably restricted the issuance of a subpoena authorized by law would be open to question. The legislative history of the act, however, indicates that it was thought to do no more than confer upon private parties "the same access to subpoenas as that available to the representatives of agencies." Senate Conm. ON THE Judrciary, 79TH Cong. 2d Sess., Administrative Procedure Act-Legislative History 206, 265 (Comm. Print 1946) (Senate and House committee reports).

If, however, a rule were promulgated which denied the availability of a privilege, it would clearly be open to challenge in a judicial proceeding to enforce a subpoena. It would be claimed that the rule was invalid and that the privilege obtained. The focus of attention would be upon the scope of the agency's rule-making power. Rather than inquire into whether a statutory policy against the privilege could be ascertained the court would evaluate the agency's assertion that it had the power to create such a policy by rule. The $\mathrm{CAB}$, for example, is empowered "to make and amend such general or special rules, regulations, and procedure, pursuant to and consistent with the provisions of this Act, as it shall deem necessary to carry out the provisions of, and to exercise and perform its powers and duties under, this Act," 72 Stat. 743 (1958), 49 U.S.C. $\S 1324$ (a) (1958). This section would be read in conjunction with the blanket power to compel testimony and inspect premises and records granted to the Board as to air carriers and those having control over, or affiliated with an air carrier. See 72 Stat. 766, 770, 792, 49 U.S.C. $\$ \$ 1377$ (a), (e), 1385, 1484(b). Only a finding that the rule denying a privilege was inconsistent with the grant of investigative power would support a judgment that it was beyond the rule-making power granted by Congress and thus of no effect. Cf. 1 DAvis $\$ 5.03$. 
and the problem has not yet reached political proportions on a scale that can stimulate congressional action. ${ }^{82}$ Since no legislative solution is in sight it is the responsibility of the federal bench to give more than lip service to the complex problems of federalism raised by competing claims of federal and state interests. Privilege policies have been adopted to meet the needs of specialized relationships as measured by state legislatures. These policies may be relied upon by the public and they should not be abrogated in the absence of a showing that the successful prosecution of a federal program requires access to a type of information which would be protected under state law. The existence of subpoena power does not on its face "require or provide" that state privilege law is an inadequate ground for resistance to administrative inquiry.

82 A recent and notable exception to the usual rule of congressional inadvertence to privilege problems is the Antitrust Givil Process Act. The Attorney General is given the power to demand the production of any document relevant to a civil antitrust investigation with the exception, inter alia, that no demand may "require the production of any documentary evidence which would be privileged from disclosure if demanded by a subpoena duces tecum issued by a court of the United States in aid of a grand jury investigation of such alleged antitrust violation." 76 Stat. 548, 549 (1962), 15 U.S.C. $\S 1312$ (c)(2) (Supp. IV, 1963). The Federal Rules of Criminal Procedure provide that "the admissibility of evidence and the competency and privileges of witnesses shall be governed, except when an act of Congress or these rules otherwise provide, by the principles of the common law as they may be interpreted by the courts of the United States in the light of reason and experience." FED. R. CRIM. P. 26. The power to declare rules of privilege has been exercised by the courts in the course of compelling compliance with the requirements of subpoenas issued on behalf of a grand jury. See, e.g., Schwimmer v. United States, 232 F.2d 855, 863-66 (8th Cir.), cert. denied, 352 U.S. 833 (1956) (attorney-client); Petition of Borden Co., 75 F. Supp. 857, 858-59 (N.D. Ill. 1948) (refusal to follow state accountant-client privilege). 